\title{
Enhancement of Bone-Like Apatite Forming Abilities of Calcium Phosphate Ceramics in SBF by Autoclaving
}

\author{
Akiko OBATA, Tatsuya FUJIMOTO and Toshihiro KASUGA \\ Department of Materials Science and Engineering, Graduate School of Engineering, Nagoya Institute of Technology, \\ Gokiso-cho, Showa-ku, Nagoya-shi 466-8555 \\ オートクレーブ法による $\beta$-リン酸三カルシウム及び水酸アパタイトの \\ 骨類似アパタイト形成能の促進 \\ 小幡亜希子 · 藤本達也 · 春日敏宏 \\ 名古屋工業大学大学院工学研究科, 466-8555 名古屋市昭和区御器所町
}

\begin{abstract}
Bone-like hydroxyapatite (b-HA) formation abilities of $\beta$-tricalcium phosphate $(\beta$-TCP) and hydroxyapatite (HA) after autoclaving were evaluated by immersion tests using simulated body fluid (SBF). The b-HA formation was observed on an autoclaved $\beta$-TCP, while no deposition was observed on the non-autoclaved one. The b-HA formation on HA was observed to be enhanced after autoclaving. Decrease of surface potentials by autoclaving may enhance the b-HA formation abilities.
\end{abstract}

[Received August 19, 2005; Accepted October 20, 2005]

Key-words : $\beta$-tricalcium phosphate, Hydroxyapatite, Simulated body fluid, Bone-like hydroxyapatite, Autoclaving

\section{Introduction}

Calcium phosphate ceramics, such as $\beta$-tricalcium phospate $\left(\beta\right.$-TCP), hydroxyapatite $(\mathrm{HA})$, Cerabone A-W $\mathrm{W}^{\circledR}$ and Bioglass $^{\circledR}$, have been commonly known to have high biocompatibility and bioactivity. These ceramics were investigated as various bone substitutes and applied to bioactive coating on bioinert materials. ${ }^{1-3)}$ Bone-like hydroxyapatite (b-HA) layer intervenes between new bone and implanted surface-active ceramics such as HA, Cerabone A-W ${ }^{\circledR}$ and Bioglass ${ }^{\circledR}{ }^{\circledR}{ }^{4,5)}$ It was reported that HA bonded to bone directly or via a comparatively thin b-HA layer, and the b-HA layer with about 0.5 $\mu \mathrm{m}$ in thickness intervened between bone and Cerabone A$\mathrm{W}^{\circledR}$ or Bioglass ${ }^{\circledR} .{ }^{5)}$ On the other hand, new bone is directly formed on the surfaces of resorbable ceramics such as $\beta$-TCP after implantation in bone. These various reactions in the new bone formation depending on implanted ceramics were suspected to originate from differences in the chemical composition, crystallinity and resorbability of the ceramics in body.

The b-HA may be regarded as one of the important factors for cellular biocompatibility and bone boning ability of the bioactive materials. ${ }^{6}$ ) Simulated body fluid (SBF) is widely used to demonstrate surface reactions and the b-HA formation on the bioactive materials implanted in body. ${ }^{7}$ Recently, we found that b-HA forming ability on $60 \mathrm{CaO} \cdot 30 \mathrm{P}_{2} \mathrm{O}_{5}$. $3 \mathrm{TiO}_{2} \cdot 7 \mathrm{Na}_{2} \mathrm{O}$ glass-ceramic can be enhanced after autoclaving in water or SBF. ${ }^{8)-10)}$ Bonding around titanium ions in the glassy phases is broken to form a new anatase phase at the surface during the autoclaving, and $\mathrm{Ti}-\mathrm{OH}$ group, which may induce b-HA nucleation, formed on anatase. When the autoclaved glass-ceramic is immersed in SBF, the negatively charged, hydrated titania groups and anatase crystals around the surface are believed to induce the b-HA nucleation. As a result, the b-HA forms in a short period. This autoclaving can be regarded as a typical chemicovectorial effect.

If the autoclaving method would be also applicable to some calcium phosphate materials, excellently bioactive materials could be easily prepared. In this work, $\beta$-TCP and HA ceramics were autoclaved in water and the b-HA formation on their surfaces in SBF were examined.

\section{Materials and methods}

$\beta$-TCP and HA samples were prepared using reagents of Taihei Chemical Industrial Co., Ltd. The reagents were uniaxially pressed under $19.6 \mathrm{MPa}$ in a $10-\mathrm{mm}$ diameter mold, and subsequently the obtained discs were isostaticaly pressed under $98 \mathrm{MPa}$ for $15 \mathrm{~min}$. The obtained green discs were heated at a ramp rate of $5^{\circ} \mathrm{C} \mathrm{min}^{-1}$ in an electric furnace and retained for $3 \mathrm{~h}$ at $1070^{\circ} \mathrm{C}$ for $\beta$-TCP and at 1100 or $1400^{\circ} \mathrm{C}$ for HA. The sintered samples were autoclaved in distilled water $(\mathrm{DW})$ at $100-180^{\circ} \mathrm{C}$ for $1 \mathrm{~h}$. The sample surfaces before and after autoclaving were analyzed by thin-film X-ray diffractometry (TF-XRD; Philips, Xpert-MPD). TF-XRD analysis was carried out at a glancing angle of $1^{\circ}, 50 \mathrm{kV}$ and $40 \mathrm{~mA}$.

SBF containing $2.5 \mathrm{mM}$ of $\mathrm{Ca}^{2+}, 142.0 \mathrm{mM}$ of $\mathrm{Na}^{+}, 1.5$ $\mathrm{mM}$ of $\mathrm{Mg}^{2+}, 5.0 \mathrm{mM}$ of $\mathrm{K}^{+}, 148.8 \mathrm{mM}$ of $\mathrm{Cl}^{-}, 4.2 \mathrm{mM}$ of $\mathrm{HCO}_{3}{ }^{-}, 1.0 \mathrm{mM}$ of $\mathrm{HPO}_{4}{ }^{2-}, 0.5 \mathrm{mM}$ of $\mathrm{SO}_{4}{ }^{2-}, 50 \mathrm{mM}$ of $\left(\mathrm{CH}_{2} \mathrm{OH}\right)_{3} \mathrm{CNH}_{2}$ and $45.0 \mathrm{mM}$ of $\mathrm{HCl}$ was prepared using reagents of $\mathrm{NaCl}, \mathrm{NaHCO}_{3}, \mathrm{KCl}, \mathrm{K}_{2} \mathrm{HPO} 4 \cdot 3 \mathrm{H}_{2} \mathrm{O}, \mathrm{MgCl}_{2}$. $6 \mathrm{H}_{2} \mathrm{O}, \mathrm{HCl}, \mathrm{CaCl}_{2}, \mathrm{NaSO}_{4}$ and $\mathrm{NH}_{2} \mathrm{C}\left(\mathrm{CH}_{2} \mathrm{OH}\right)_{3}$ (all reagents were purchased from Kishida Chemical Co., Ltd.) in DW at

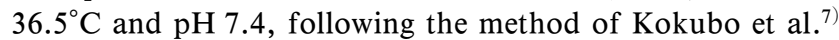
The samples were immersed in $100 \mathrm{ml}$ of SBF and retained at $37^{\circ} \mathrm{C}$. After $10 \mathrm{~d}$ immersion, the samples were washed with deionized water and dried at room temperature. Surfaces of the samples after immersion in SBF were observed by a field emission scanning electron microscopy (FE-SEM; JSM$6301 \mathrm{~F}$, JEOL) with an acceleration voltage of $10 \mathrm{kV}$. The samples for SEM were coated with osmium prior to observation.

Zeta potentials of the sample surfaces were measured by a laser electrophoresis spectroscopy (Otsuka Electronics Co., Ltd., ELS-6000KS) adopting a laser Duppler electrophoresis. For this measurement, the sintered samples were cut in $10 \times 40$ $\times 1 \mathrm{~mm}$ using a diamond saw. After polished, the samples were autoclaved at $160^{\circ} \mathrm{C}$ for $1 \mathrm{~h}$ in $\mathrm{DW}$. The measurement 
was immediately curried out after immersion in $\mathrm{SBF}$ at $37.5^{\circ} \mathrm{C}$ with $80 \mathrm{~V}$.

\section{Results and discussion}

Figure 1 shows TF-XRD spectra of $\beta$-TCP and HA sintered at $1100^{\circ} \mathrm{C}$ before and after the autoclaving. The spectra of $\beta$-TCP and HA indicate no difference in the phases between before and after the autoclaving.

Figure 2 shows the SEM micrographs of the non-autoclaved and autoclaved $\beta$-TCP samples after immersion in SBF. The SEM micrograph of the non-autoclaved $\beta$-TCP surface (Fig. 2[a]) shows no deposit on the surface after the immersion in SBF. On the other hand, the deposition of the leaf-like deposits of approximately $1-2 \mu \mathrm{m}$ in diameter was observed on all of the autoclaved $\beta$-TCP surfaces. Quantity and dimension of the deposits increased with increasing of the autoclaving temperature. The deposits with about $1 \mu \mathrm{m}$ in diameter dispersed on the surface of the $\beta$-TCP autoclaved at 100 and $120^{\circ} \mathrm{C}$, and those with about $2 \mu \mathrm{m}$ in diameter were observed on the surface of the $\beta$-TCP autoclaved at $140-180^{\circ} \mathrm{C}$. The

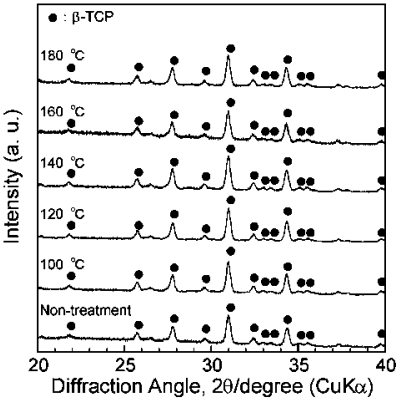

[a]

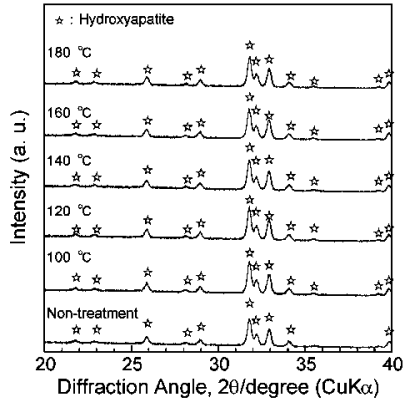

[b]
Fig. 1. TF-XRD spectra of $\beta$-TCP and HA, sintered at 1070 and $1100^{\circ} \mathrm{C}$, respectively, before and after autoclaving. $[\mathrm{a}] \beta-\mathrm{TCP}$, [b] HA. deposits densely formed on the $\beta$-TCP autoclaved at $160^{\circ} \mathrm{C}$ and $180^{\circ} \mathrm{C}$. Although it was difficult to identify the leaf-like deposits from TF-XRD, the deposits are considered to be b-HA, judging from the morphology and situation (e.g., supersaturation degree) in SBF.

Figure 3 shows the surfaces of the non-autoclaved and autoclaved $\mathrm{HA}$, sintered at $1100^{\circ} \mathrm{C}$, after immersion in SBF. The SEM observation showed that the b-HA formation was influenced by autoclaving. On the non-autoclaved HA, the b-HA aggregated to granules of approximately $1-2 \mu \mathrm{m}$ in diameter and dispersed on the surface. The surfaces of the autoclaved HA were covered with the leaf-like b-HA, and the aggregates of the b-HA crystals of $>1-\mu \mathrm{m}$ diameter also deposited on the b-HA layer.

Figure 4 shows highly magnified SEM micrographs before and after autoclaving $\beta$-TCP. The smooth surface of the nonautoclaved $\beta$-TCP was changed into the rough surface in the order of several hundred nanometers after autoclaving.

The zeta potential of $\beta$-TCP before and after autoclaving were approximately -8 and $-16 \mathrm{mV}$, respectively. The zeta potential of HA sintered at $1100^{\circ} \mathrm{C}$ before and after autoclaving were the same values as those of $\beta$-TCP. The decrease in the zeta potential was supposed to originate from hydrated group formation on the $\beta$-TCP and HA surfaces during the autoclaving. In our earlier work, negatively charged, hydrated titania groups were reported to form on the surface of the phosphate glass-ceramic consisting of $\beta$-TCP, $\beta$ - $\mathrm{Ca}_{2} \mathrm{P}_{2} \mathrm{O}_{7}$ and a small amount of glassy phase containing $\mathrm{TiO}_{2}$ and $\mathrm{Na}_{2} \mathrm{O}$ during the autoclaving, and to enhance the b-HA formation on the glass-ceramic surface in SBF. ${ }^{8)}{ }^{-10}$ ) In the present work, numerous groups such as $\mathrm{PO}_{4} \mathrm{H}_{2}$, which induce b-HA nucleation, are believed to form on the surfaces of the $\beta$-TCP and HA during the autoclaving. The negatively charged, hydrated groups on the autoclaved $\beta$-TCP and HA surfaces may induce plus ions such as $\mathrm{Ca}^{2+}$, which play an important role in the b-HA nucleation, to the surfaces and enhance the b-HA formation. ${ }^{11)}$ In addition, the zeta potential of $-16 \mathrm{mV}$ on $\beta$-TCP and HA surfaces was expected to be enough to enhance
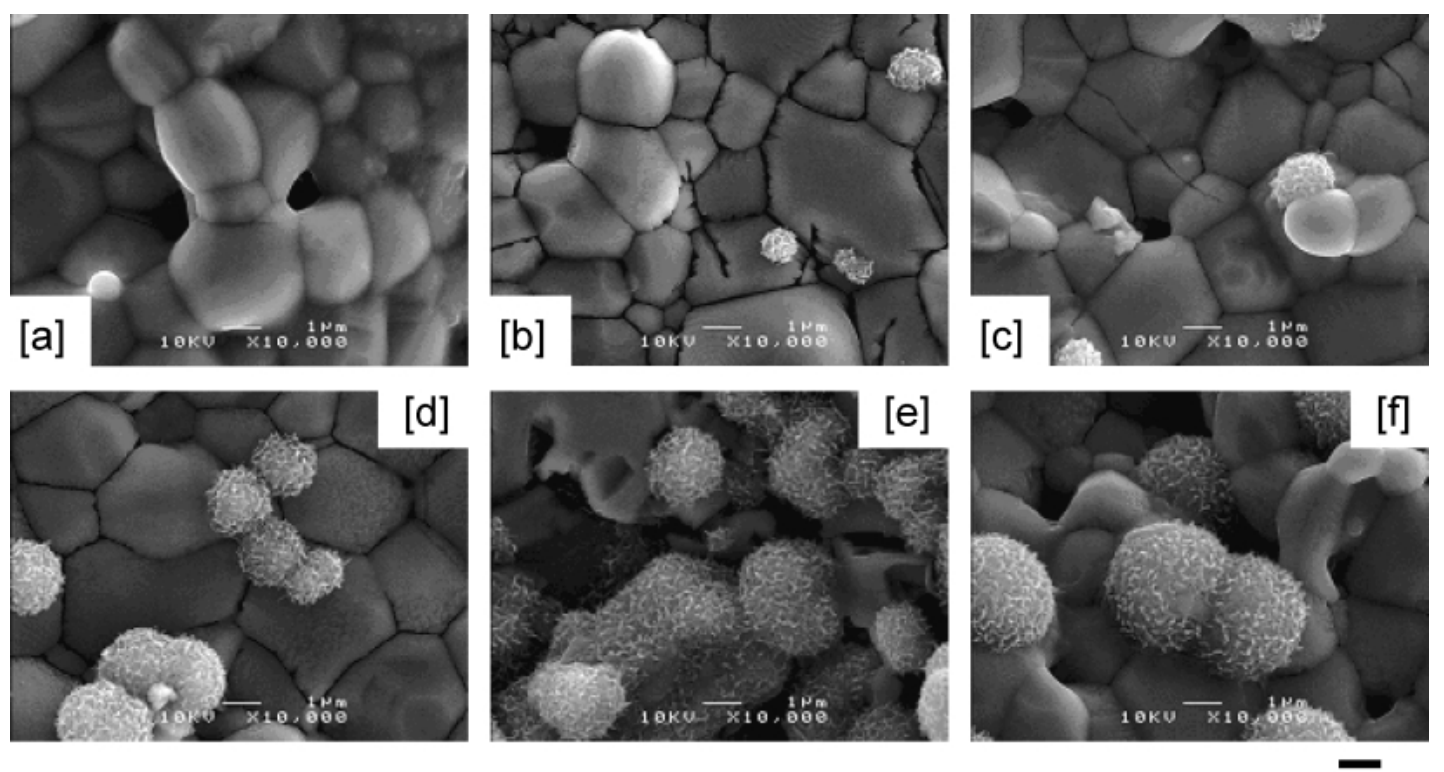

$1 \mu \mathrm{m}$

Fig. 2. Surface morphologies of $\beta$-TCP after $10 \mathrm{~d}$ of immersion in SBF. [a] non-autoclaved sample, samples autoclaved at $[\mathrm{b}] 100^{\circ} \mathrm{C}$, $[\mathrm{c}] 120^{\circ} \mathrm{C},[\mathrm{d}] 140^{\circ} \mathrm{C},[\mathrm{e}] 160^{\circ} \mathrm{C},[\mathrm{f}] 180^{\circ} \mathrm{C}$. 

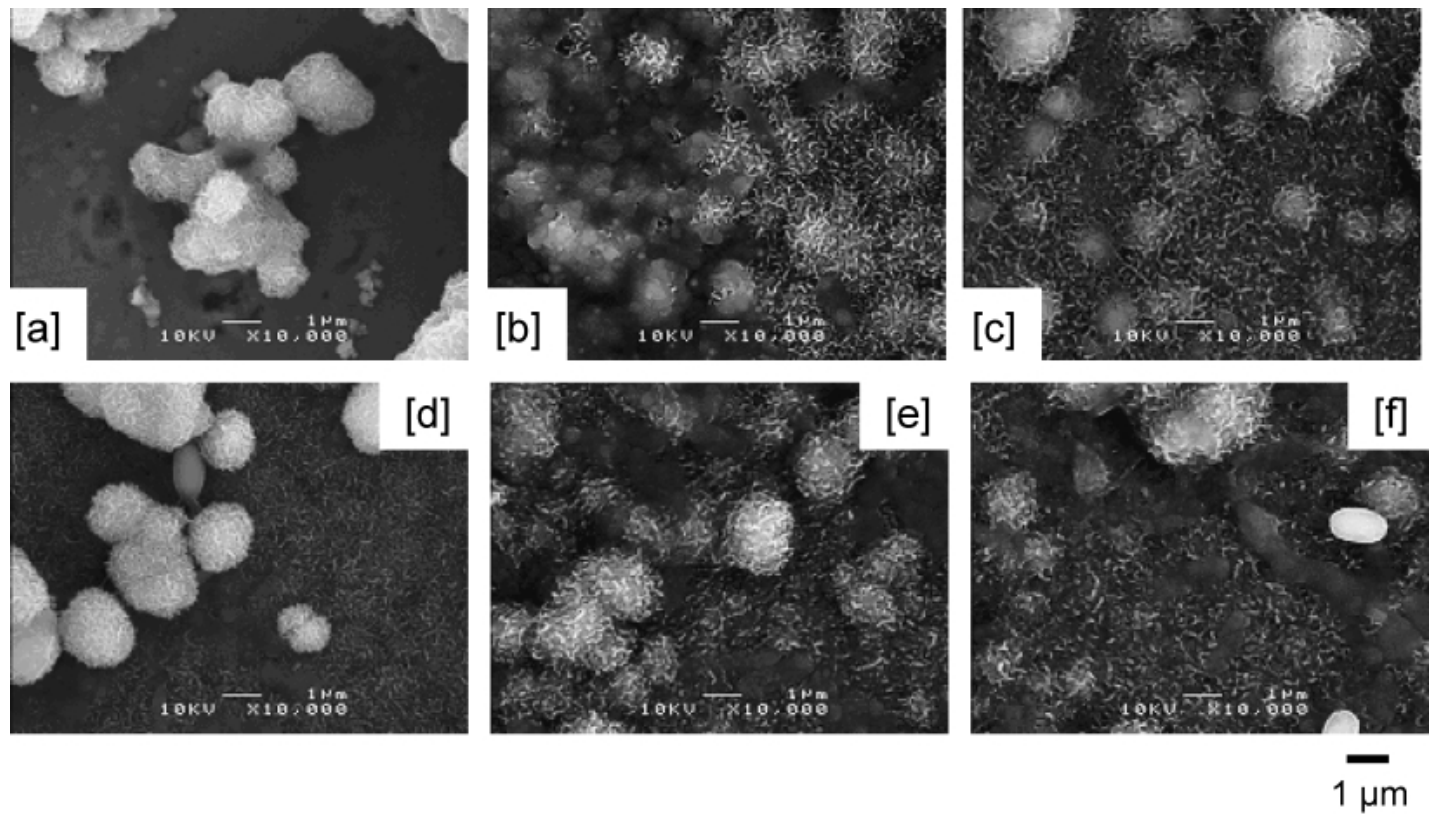

Fig. 3. Surface morphologies of $\mathrm{HA}$, sintered at $1100^{\circ} \mathrm{C}$, after $10 \mathrm{~d}$ of immersion in SBF. [a] non-autoclaved sample, samples autoclaved at $[\mathrm{b}] 100^{\circ} \mathrm{C},[\mathrm{c}] 120^{\circ} \mathrm{C},[\mathrm{d}] 140^{\circ} \mathrm{C},[\mathrm{e}] 160^{\circ} \mathrm{C},[\mathrm{f}] 180^{\circ} \mathrm{C}$.
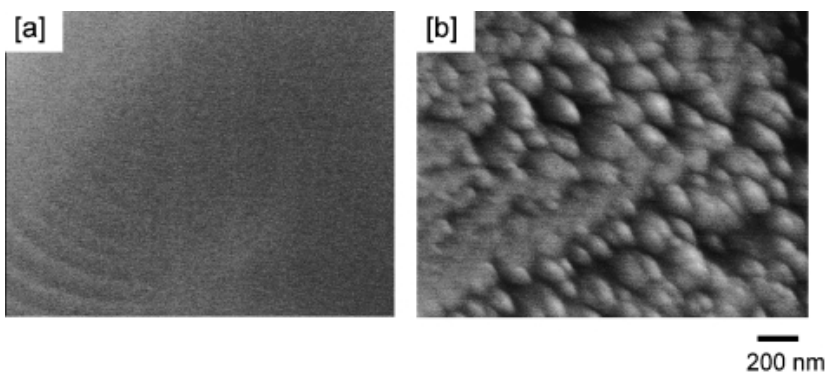

Fig. 4. Highly magnified images of the $\beta$-TCP surfaces before and after autoclaving. $[\mathrm{a}]$ before autoclaving and $[\mathrm{b}]$ after autoclaving.

the b-HA formation on each surface. The present work shows that the b-HA forming ability of the $\beta$-TCP, which is one of the crystalline phases in the glass-ceramics, is also enhanced by autoclaving. Therefore, the enhanced b-HA forming ability of the glass-ceramics was suggested to originate from the surface modification of both of the glassy and crystalline phases.

The b-HA is reported to play an important role in bone mineralization processes between implanted biomaterials and host bone. The b-HA formation is believed to provide an essential condition for biomaterials to bond to bone. In vitro and in vivo surface reactions and the b-HA forming ability of $\beta$-TCP have been reported by many researchers. ${ }^{12)-16)}$ Ohtsuki et al. reported no formation of b-HA layer on $\beta$-TCP after $120 \mathrm{~d}$ of immersion in SBF. ${ }^{12)}$ Contrary to his report, Ribeiro et al. revealed hydroxycarbonate apatite was deposited on $\beta$-TCP in $15 \mathrm{~d}$ of immersion in SBF. ${ }^{13)} \mathrm{Neo}$ and Kotani et al. showed that $\beta$-TCP directly bonded to bone intervening no apatite layer by in vivo tests. ${ }^{4), 14), 15)}$ On the other hand, Daculsi et al. reported formation of carbonate apatite layer in the vicinity of implanted $\beta$-TCP. ${ }^{16)}$ However, connectivity of $\beta$-TCP with host bone was reported to be strong in general and attributed to rough surface due to degradation of implanted $\beta$-TCP. In this work, the b-HA formation was observed on the autoclaved $\beta$-TCP after $10 \mathrm{~d}$ of immersion in SBF and suspected to be attributed to the low surface potential and the rough surface generated by autoclaving. The b-HA formation of $\beta$-TCP enhanced by autoclaving may provide the higher bonebonding ability to $\beta$-TCP in vivo.

$\mathrm{Neo}$ et al. reported that the indistinct appearance or partial absence of the b-HA layer were observed between implanted $\mathrm{HA}$ and the host bone and consistent with the solubility of HA. ${ }^{4)}$ The b-HA layer formed on the HA surface is also regarded as one of the important factors for bonding to host bone in vivo. The b-HA formation ability enhanced by the autoclaving was expected to provide the excellent bone-bonding ability to HA and make the strong fixation with bone in vivo.

Next, the influence of the autoclaving on HA sintered at high temperature, that is $1400^{\circ} \mathrm{C}$, was examined. Figure 5 shows the surface morphologies of the non-autoclaved and autoclaved HA, sintered at $1400^{\circ} \mathrm{C}$, after immersion in SBF. No deposit was observed, whether the autoclaved or nonautoclaved sample. Since the HA sintered at $1400^{\circ} \mathrm{C}$ has higher crystallinity than that sintered at $1100^{\circ} \mathrm{C}$, almost no modification of the surface of the HA sintered at $1400^{\circ} \mathrm{C}$ may occur. Klein reported that increase in the crystallinity of HA promotes its stability and the enhanced stability decreases the solubility and the ion releasability from the HA surface. ${ }^{3)}$ The poor b-HA forming ability on the HA sintered at $1400^{\circ} \mathrm{C}$ even after autoclaving may be caused by high chemical durability.

\section{Conclusion}

The b-HA forming abilities of $\beta$-TCP and HA sintered at $1100^{\circ} \mathrm{C}$ in SBF were enhanced by autoclaving in DW. The b-HA was observed on the autoclaved $\beta$-TCP after $10 \mathrm{~d}$ of immersion, while no deposit was observed on the non-autoclaved one. The enhancement of the b-HA formation may originate from the appearance of negatively charged, hydrated groups on the $\beta$-TCP and HA surfaces after the autoclaving. The b-HA formation is regarded as one of the important factors for the bone-bonding in body. The autoclaving was expected 

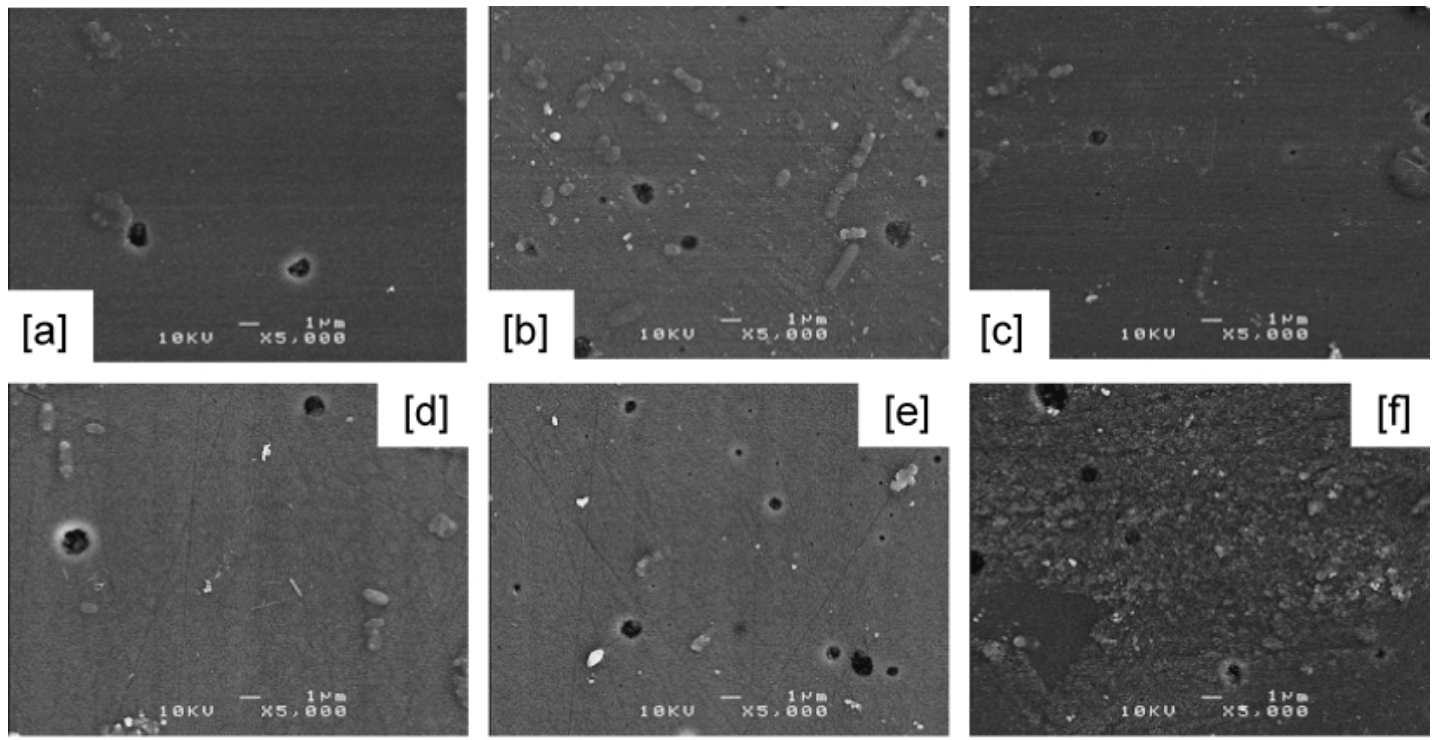

$2 \mu \mathrm{m}$

Fig. 5. Surface morphologies of HA, sintered at $1400^{\circ} \mathrm{C}$, after $10 \mathrm{~d}$ of immersion in SBF. [a] non-autoclaved sample, samples autoclaved at [b] $100^{\circ} \mathrm{C},[\mathrm{c}] 120^{\circ} \mathrm{C},[\mathrm{d}] 140^{\circ} \mathrm{C},[\mathrm{e}] 160^{\circ} \mathrm{C},[\mathrm{f}] 180^{\circ} \mathrm{C}$.

to be useful method for providing the excellent bioacitivity and bone-bonding ability to some calcium phosphate materials. However, the b-HA forming ability of HA ceramic sintered at high temperature, e.g., $1400^{\circ} \mathrm{C}$, could not be enhanced by autoclaving. Generation of the enhancing effect may be controlled by the crystallinity of HA.

Acknowledgement This work was supported in part by NITEC 21st Century COE Program "World Ceramic Center for Environmental Harmony".

\section{References}

1) Hench, L. L., J. Am. Ceram. Soc., Vol. 81, pp. 1705-1728 (1998).

2) Kondo, N., Ogose, A., Tokunaga, K., Ito, T., Arai, K., Kudo, N., Inoue, H., Irie, H. and Endo, N., Biomater., Vol. 26, pp. 5600-5608 (2005).

3) Hench, L. L. and Wilson, J., "An Introduction to Bioceramics," World Scientific (1993).

4) Neo, M., Kotani, S., Fujita, Y., Nakamura, T., Yamamuro, T., Bando, Y., Ohtsuki, C. and Kokubo, T., J. Biomed. Mater. Res., Vol. 26, pp. 255-267 (1992).

5) Neo, M., Kotani, S., Nakamura, T., Yamamuro, T., Ohtsuki, C., Kokubo, T. and Bando, Y., J. Biomed. Mater. Res., Vol. 26, pp. 1419-1432 (1992).
6) Ducheyne, P. and Qiu, Q., Biomater., Vol. 20, pp. 2287-2303 (1999).

7) Kokubo, T., Kushitani, H., Sakka, S., Kitsugi, T. and Yamamuro, T., J. Biomed. Mater. Res., Vol. 24, pp. 721-734 (1990).

8) Kasuga, T., Fujimoto, T., Hosoi, Y. and Nogami, M., Key Eng. Mater., Vols. 240-242, pp. 265-268 (2003).

9) Kasuga, T., Fujimoto, T. and Nogami, M., J. Ceram. Soc. Japan, Vol. 111, pp. 633-635 (2003).

10) Kasuga, T., Fujimoto, T., Wang, C. and Nogami, M., Key Eng. Mater., Vols. 254-256, pp. 753-756 (2004).

11) Ohtsuki, C., Kokubo, T. and Yamamuro, T., J. Non-Cryst. Solid, Vol. 143, pp. 84-92 (1992).

12) Ohtsuki, C., Kokubo, T., Kotani, S. and Yamamuro, T., Proc. 12th Ann. Meet., Jpn. Soc. Biomater., pp. 99-99 (1990).

13) Ribeiro, C., Rigo, E. C. S., Sepulveda, P., Bressiani, J. C. and Bressiani, A. H. A., Mater. Sci. Eng. C, Vol. 24, pp. 631-636 (2004).

14) Neo, M., Herbst, H., Voigt, C. F. and Gross, U. M., J. Biomed. Mater. Res., Vol. 39, pp. 71-76 (1998).

15) Kotani, S., Fujita, Y., Kitsugi, T., Nakamura, T., Yamamuro, T., Ohtsuki, C. and Kokubo, T., J. Biomed. Mater. Res., Vol. 25, pp. 1303-1315 (1991).

16) Daculsi, G., LeGeros, R. Z., Heughebaert, M. and Barbieux, I., Calcif. Tissue Int., Vol. 46, pp. 20-27 (1990). 